\title{
Hexapeptides from human milk prevent the induction of oxidative stress from parenteral nutrition in the newborn guinea pig
}

\author{
Khalil Miloudi', Apollinaire Tsopmo ${ }^{2}$, James K. Friel ${ }^{3}$, Thérèse Rouleau' ${ }^{1}$, Blandine Comte ${ }^{4}$ and Jean-Claude Lavoie ${ }^{1}$
}

INTRODUCTION: In preterm neonates, peroxides contaminating total parenteral nutrition (TPN) contribute to oxidative stress, which is suspected to be a strong inducer of hepatic complications related to prematurity. Recently, others reported that hexapeptides derived from human milk (HM) exerted free radical-scavenging activities in vitro. Therefore, the aim of this study was to assess the capacity of these hexapeptides to limit the generation of peroxides in TPN and to prevent TPN-induced hepatic oxidative stress.

METHODS: At 3 d of life, guinea pigs were infused, through a catheter in jugular vein, with TPN containing or not peptide-A (YGYTGA) or peptide-B (ISELGW). Peroxide concentrations were measured in TPN solutions, whereas glutathione, glutathionyl-1,4-dihydroxynonenal (GS-HNE) and mRNA levels of interleukin-1 (IL-1) and tumor necrosis factor-a (TNFa) were determined in liver after $4 \mathrm{~d}$ of infusion.

RESULTS: The addition of peptide-A to TPN allowed a reduction in peroxide contamination by half. In vivo, peptide-A or peptide-B corrected the hepatic oxidative status induced by TPN. Indeed, both peptides lowered the hepatic redox potential of glutathione and the level of GS-HNE, a marker of lipid peroxidation. As compared with animals infused with TPN without peptide, the hepatic mRNA levels of IL-1 and TNFa were lower in animals infused with TPN containing peptide-A or peptide-B.

DISCUSSION: These results suggest that the addition of YGYTGA or ISELGW to TPN will reduce oxidative stress in newborns. The reduction in mRNA of two proinflammatory cytokines could be important for the incidence of hepatic complications related to TPN.

O xidative stress is present in very-low-birth-weight preterm newborns (1) and is suspected to play a key role in several complications of prematurity. Although the contribution of oxygen supplementation is recognized (1), total parenteral nutrition (TPN) is also an important source of oxidants. Peroxides in TPN are derived mainly from the reduction of dissolved oxygen by electron donors such as vitamin $\mathrm{C}$, amino acids, and lipids (2). These reactions are catalyzed by ambient light through photosensitive riboflavin (2). Complete photoprotection reduced the generation of peroxides by half (1); however, this is not practical in the neonatal unit. During reactions occurring in TPN, several reactive components are produced, including hydrogen peroxide (3), lipid hydroperoxides (4), and 4-hydroxynonenal (4-HNE; ref. 5).

In vivo, 4-HNE is detoxified by conjugation with glutathione (6). Preterm infants, who have an immature antioxidant system (7) and low glutathione levels (8), are at risk to develop several pathological complications, such as bronchopulmonary dysplasia, retinopathy of prematurity, and hepatocellular injury (9-11). Therefore, reactive molecules, such as 4-HNE, can interfere with proteins (12), lipids (13), and DNA (14); disrupt the cellular redox balance (15); act on cell signaling; and induce inflammatory response by activating the nuclear factor- $\kappa$ B pathway (16).

It is well known that human milk (HM) promotes antioxidant capacity in the newborn as compared with artificial milk (AM) (17). This property is associated with a greater free radical-scavenging capacity $(18,19)$. However, at the time when very-low-birth-weight premature newborns are nourished with TPN, their gastrointestinal tract is too immature to receive significant amounts of HM. Recently, Tsopmo et al. (20) isolated two hexapeptides from enzymatic hydrolysates of HM possessing a high free radicalscavenging capacity in vitro (20). We hypothesized that the addition of those peptides to TPN could be a valuable alternative to light protection. Therefore, the aims of this study were to assess the scavenging capacity of these peptides in the prevention of oxidation of TPN components and to test the ability of peptides added to TPN to (i) reduce the hepatic level of oxidative stress markers, especially 4 -HNE, and (ii) to prevent the induction of two proinflammatory cytokines: tumor necrosis factor- $\alpha$ (TNF $\alpha$ ) and interleukin-1 (IL-1). Since these peptides were derived from HM, animals were nourished or not with HM in order to generate reference values.

\footnotetext{
'Department of Pediatrics, University of Montreal, Montréal, Quebec, Canada; '2Department of Chemistry, Carleton University, Ottawa, Ontario, Canada; ${ }^{3}$ Department of Human Nutritional Sciences and Paediatrics, University of Manitoba, Winnipeg, Manitoba, Canada; ${ }^{4}$ Unité de Nutrition Humaine, Université d'Auvergne, Clermont-Ferrand, France. Correspondence: Jean-Claude Lavoie (jean-claude.lavoie@umontreal.ca) 


\section{RESULTS}

The levels of peroxides generated in TPN solutions (Figure 1) were lower $\left(F_{(1,12)}=10.2 ; P<0.01\right)$ in the presence of peptide-A (YGYTGA) without any difference $\left(F_{(1,12)}=0.5\right)$ at varying concentrations (10-40 mmol/l). Peptide-B (ISELGW) was without effect $\left(F_{(1,12)}<1.4\right)$.

An interaction $\left(F_{(1,24)}>8.9 ; P<0.01\right)$ between the parameters influencing the hepatic redox potential of glutathione (Figure 2a) allowed us to reanalyze the data in the presence or absence of intravenous $\mathrm{H}_{2} \mathrm{O}_{2}$. In the absence of peroxide, redox potential was less oxidized $\left(F_{(1,24)}=18.5 ; P<0.01\right)$ in the HM than the AM group, but no difference was observed $\left(F_{(1,24)}=\right.$ 0.01 ) between the HM and the control (C) groups. In animals infused with $\mathrm{H}_{2} \mathrm{O}_{2}$, there was no difference between the HM and AM groups $\left(F_{(1,24)}=1.1\right)$. However, redox potential was more oxidized in the HM and AM groups as compared with the $\mathrm{C}$ group $\left(F_{(1,24)}=16.9 ; P<0.01\right)$.

The diet effect on the redox potential seems to be linked to changes in the levels of the reduced form of glutathione (GSH)
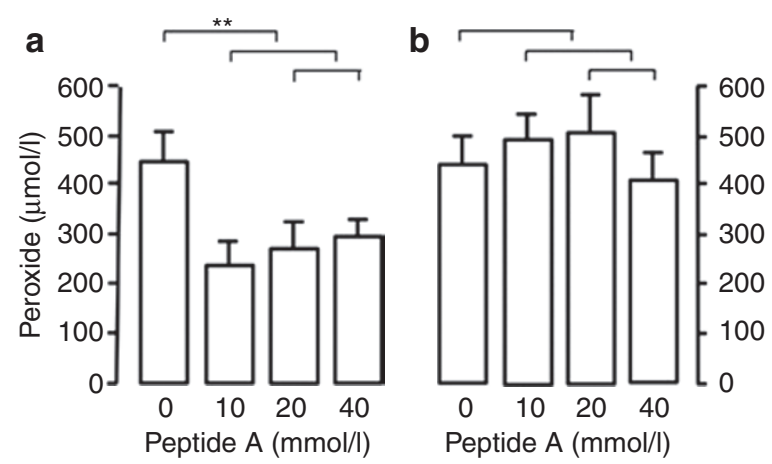

Figure 1. Concentration of peroxides in TPN solutions in the presence of peptide-A or peptide-B. (a) The concentration of peroxides was lower in TPN solution in the presence of peptide-A (YGYTGA) independent of the concentration of peptide. (b) Peptide-B (ISELGW) was without effect on the generation of peroxides in TPN solution; mean \pm SEM, $n=4 ;{ }^{* *} P<0.01$. TPN, total parenteral nutrition.
(Table 1), as the results of statistical analyses were similar: (i) interaction between parameters $\left(F_{(1,24)}>9.1 ; P<0.01\right)$; (ii) in the absence of $\mathrm{H}_{2} \mathrm{O}_{2}$, GSH levels were higher in the HM group than they were in the AM group $\left(F_{(1,24)}=19.0 ; P<0.01\right)$, without difference $\left(F_{(1,24)}=0.04\right)$ with the $C$ group; and (iii) in the presence of $\mathrm{H}_{2} \mathrm{O}_{2}$, GSH levels did not differ between the HM and AM groups $\left(F_{(1,24)}=0.2\right)$, but were lower than those of the $\mathrm{C}$ group $\left(F_{(1,24)}=16.7 ; P<0.01\right)$. Conversely, there was no interaction $\left(F_{(1,24)}<2.6\right)$ between the parameters for the disulfide form of glutathione (GSSG). Its level, similar in the HM and AM groups $\left(F_{(1,24)}=0.1\right)$, was lower with the $C$ group $\left(F_{(1,24)}=5.0\right.$; $P<0.05)$. There was no effect of infused peroxide $\left(F_{(1,24)}=2.4\right)$.

The interaction $\left(F_{(1,24)}=6.2 ; P<0.05\right)$ between the parameters influencing $\mathrm{F}_{2 a}$-isoprostane levels (Figure 2b) suggests that the impact of diet was dependent on the presence of $\mathrm{H}_{2} \mathrm{O}_{2}$. In the absence of $\mathrm{H}_{2} \mathrm{O}_{2}$, there was no difference between the $\mathrm{HM}, \mathrm{AM}$, and $\mathrm{C}$ groups $\left(F_{(1,24)}<0.2\right)$. In contrast, in the presence of infused $\mathrm{H}_{2} \mathrm{O}_{2}$, the $\mathrm{F}_{2 a}$-isoprostane level was higher $\left(F_{(1,24)}=15.7 ; P<0.01\right)$ in the AM group than in the HM and $\mathrm{C}$ groups. There was no difference between the $\mathrm{HM}+\mathrm{H}_{2} \mathrm{O}_{2}$ and the $\mathrm{C}+\mathrm{H}_{2} \mathrm{O}_{2}$ groups $\left(F_{(1,24)}=0.2\right)$. The hepatic levels of glutathionyl 1,4-dihydroxynonenal (GS-HNE) were similar $\left(F_{(1,22)}<\right.$ 3.3 ) in these six groups (Figure 2) with a mean value of $2.4 \pm$ $0.2 \mathrm{pmol} / \mathrm{mg}$ protein $(n=28)$.

As compared with the control TPN (without light protection), peptide supplementations reduced $\left(F_{(1,14)}=12.2 ; P<\right.$ $0.01)$ the hepatic redox potential (Figure $3 a)$. There was no difference between peptides $\left(F_{(1,14)}=0.2\right)$. The difference in redox potential is linked with a higher level $\left(F_{(1,14)}=7.6 ; P<0.05\right)$ of GSH (Table 2) in animals infused with TPN enriched with peptides. GSSG levels were not influenced by the presence of peptides $\left(F_{(1,14)}<1.1\right)$.

Levels of $\mathrm{F}_{2 a}$-isoprostane (Figure $3 \mathrm{~b}$ ) did not vary between groups $\left(F_{(1,14)}<2.0\right)$, whereas GS-HNE levels (Figure 3c) were lower $\left(F_{(1,14)}=9.2 ; P<0.01\right)$ in liver from animals infused with TPN enriched with peptide-A or peptide-B as compared with liver from animals receiving TPN without
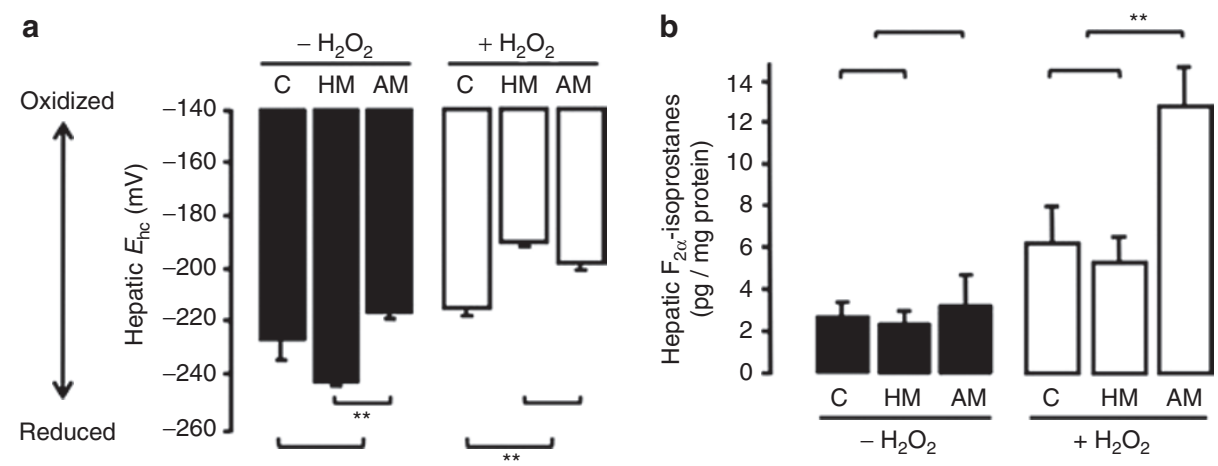

Figure 2. Redox potential of glutathione and levels of $\mathrm{F}_{2 a}$-isoprostanes in liver of animals infused with $\pm \mathrm{H}_{2} \mathrm{O}_{2}$ and fed regular chow, human milk, or artificial milk. (a) In the absence of peroxide, redox potential was more reduced in the HM group than in the AM group. In animals infused with peroxides, there was no difference in redox potential between the HM and AM groups; both were more oxidized than the $\mathrm{C}$ group. (b) In the absence of peroxide, there was no difference between the groups. In animals infused with peroxides, $\mathrm{F}_{2 a}$-isoprostane level was higher in the AM group than in the $\mathrm{HM}$ and C groups; mean \pm SEM, $n=4-6 ;{ }^{* * P}<0.01$. AM, animals fed artificial milk; $\mathrm{C}$, (control) animals fed regular chow; $\mathrm{HM}$, animals fed human milk; $\pm \mathrm{H}_{2} \mathrm{O}_{2}$, animals infused (open bars) or not infused (filled bars) with solution containing $\mathrm{H}_{2} \mathrm{O}_{2}$ at similar concentration as measured in TPN solutions; TPN, total parenteral nutrition. 
peptide. There was no difference in GS-HNE levels between animals infused with peptide-A and those infused with peptide-B $\left(F_{(1,14)}=0.2\right)$.

Hepatic mRNA of TNFa and of IL-1 (Figure 4) were lower $\left(F_{(1,14)}>4.9 ; P<0.05\right)$ when TPN was supplemented

Table 1. Glutathione levels in liver from animals infused with or without $\mathrm{H}_{2} \mathrm{O}_{2}$ and fed regular chow, human milk, or artificial milk

\begin{tabular}{lcc}
\hline & $\begin{array}{c}\mathrm{GSH} \\
(\mathrm{nmol} / \mathrm{mg} \text { protein })\end{array}$ & $\begin{array}{c}\mathrm{GSSG} \\
(\mathrm{nmol} / \mathrm{mg} \text { protein) }\end{array}$ \\
\hline $\mathrm{C}$ & $34 \pm 2$ & $0.16 \pm 0.03$ \\
$\mathrm{HM}$ & $45 \pm 6$ & $0.17 \pm 0.03$ \\
$\mathrm{C}+\mathrm{H}_{2} \mathrm{O}_{2}$ & $25 \pm 5$ & $0.24 \pm 0.03$ \\
$\mathrm{HM}+\mathrm{H}_{2} \mathrm{O}_{2}$ & $36 \pm 2$ & $0.19 \pm 0.03$ \\
$\mathrm{AM}+\mathrm{H}_{2} \mathrm{O}_{2}$ & $19 \pm 2$ & $0.25 \pm 0.02$ \\
Factorial ANOVA: & $21 \pm 2$ & $0.23 \pm 0.02$ \\
interactions & $F_{(1,25)}>9.1^{* *}$ & $F_{(1,25)}<2.6$ \\
$\pm \mathrm{H}_{2} \mathrm{O}_{2}$ & - & $F_{(1,25)}=2.4$ \\
$\mathrm{HM}$ vs. AM & - & $F_{(1,25)}=0.9$ \\
(HM-AM) vs. C & - & $F_{(1,25)}=5.0^{*}$ \\
Without $\mathrm{H}_{2} \mathrm{O}_{2}$ & & - \\
$\mathrm{HM}$ vs. AM & $F_{(1,25)}=19.0^{* *}$ & - \\
(HM-AM) vs. C & $F_{(1,25)}=0.04$ & - \\
With $\mathrm{H}_{2} \mathrm{O}_{2}$ & & \\
$\mathrm{HM}$ vs. AM & $F_{(1,25)}=0.2$ & - \\
(HM-AM) vs. C & $F_{(1,25)}=16.7^{* *}$ & - \\
\hline
\end{tabular}

The upper part of the table represents data and the lower part represents statistical analysis. Without peroxide, GSH levels were higher in the HM group $(P<0.01)$, whereas in the presence of peroxide, GSH levels did not differ between the HM and AM groups, both being lower than the $C$ group $(P<0.01)$. In contrast, there was no interaction with GSSG, which was not influenced by peroxide. GSSG levels were similar between the HM and AM groups, both being higher than the C group $(P<0.05)$; means \pm SEM, $n=4-6$.

AM, animals fed artificial milk; $C$, control animals fed regular chow: GSH, reduced form of glutathione; GSSG, disulfide form of glutathione; $\pm \mathrm{H}_{2} \mathrm{O}_{2}$, animals infused with intravenous solution with or without hydrogen peroxide at similar concentration as measured in TPN solutions; HM, animals fed human milk; TPN, total parenteral nutrition. ${ }^{*} P<0.05,{ }^{* *} P<0.01$ with peptides. The effect of peptide-A was similar to that of peptide-B on both cytokines $\left(F_{(1,14)}<1.4\right)$.

\section{DISCUSSION}

The main finding of the study is that a nutritional alternative for the prevention of oxidative stress caused by peroxide from TPN in premature newborns is possible. The results demonstrate that the peptides from HM have properties that may be useful for this population.

This study also provides evidence that enteral HM is better that $\mathrm{AM}$ in counteracting free radical injuries (lower $\mathrm{F}_{2 \alpha}$-isoprostane levels) induced by infusion of peroxides at concentrations measured in TPN solutions. In fact, AM possessed low antioxidant capacity whereas HM had a similar effect to that of regular chow. As compared with a previous report with the same animal model infused with $\mathrm{H}_{2} \mathrm{O}_{2}(21)$, measured hepatic levels of $\mathrm{F}_{2 a}$ isoprostane suggest that $\mathrm{AM}$ does not possess antioxidant effect. Our results are in agreement with the observation that urinary levels of $\mathrm{F}_{2 a}$-isoprostanes are lower in newborn infants fed HM as compared with those nourished with formula (18). However, as compared with regular chow, there was no advantage of $\mathrm{HM}$ as suggested by the absence of a beneficial effect on hepatic redox potential in animals infused with peroxides. Further comparisons of chemical compounds between chow and the milks used here could provide new information to improve the antioxidant properties of HM or AM.

If the neonates cannot be orally fed, they require TPN. When peptide-A was added to TPN, it reduced the generation of peroxides by half, similar to the results obtained with full light protection (2). This finding was not reproduced with peptide- $B$, suggesting that free radical-scavenging properties are peptide specific. Peptide-A (YGYTGA) contains two phenolic groups from tyrosyl residues $(\mathrm{Y})$ that can serve as radical scavengers (22) whereas the free radical-scavenging property of the peptide-B (ISELGW) was reported to be linked with the tryptophan residue (W) (23). As the generation of $\mathrm{H}_{2} \mathrm{O}_{2}$ in TPN is secondary to the reduction of superoxide anion (2), a further study would challenge the superoxide anion-scavenging capacity of these peptides.
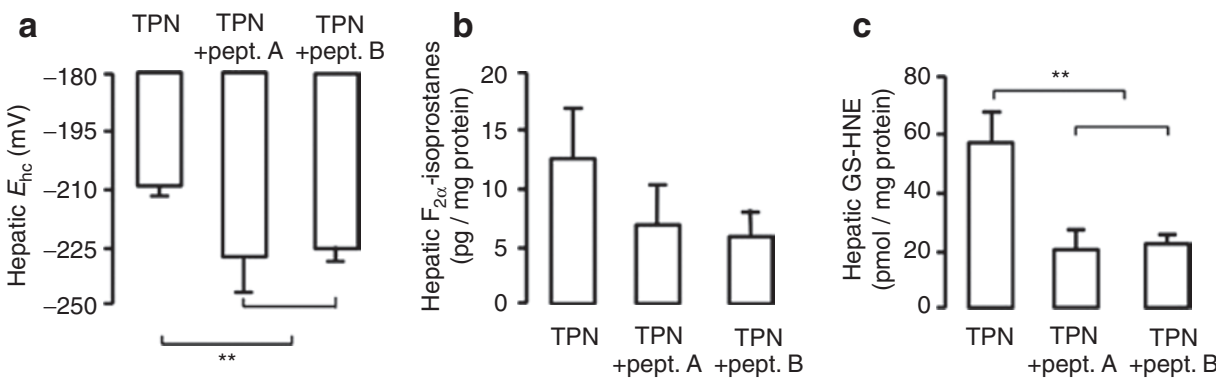

Figure 3. Oxidative stress markers in liver from animals infused with TPN with or without peptide-A or peptide-B. (a) Hepatic redox potential was more reduced if animals were infused with TPN containing peptide-A or peptide-B than in animals on TPN without peptide. The two peptides had similar effects. (b) There was no statistically significant effect of peptides on the hepatic levels of F2a-isoprostane. (c) Hepatic GS-HNE (glutathione-4-hydroxynonenal adducts) levels were lower in animals infused with TPN containing peptide-A or peptide-B than in animals receiving TPN without peptides. The two peptides had similar effects; mean \pm SEM, $n=5-6$. ${ }^{* *} P<0.01$. pept., peptide; pept.-A, YGYTGA; pept.-B, ISELGW; TPN, total parenteral nutrition. 
Table 2. Glutathione levels in liver from animals infused with TPN with or without peptide-A or peptide-B

\begin{tabular}{lcc}
\hline & $\begin{array}{c}\text { GSH } \\
\text { (nmol/mg protein) }\end{array}$ & $\begin{array}{c}\text { GSSG } \\
\text { (nmol/mg protein) }\end{array}$ \\
\hline TPN & $53 \pm 6$ & $1.3 \pm 0.2$ \\
TPN + peptide-A & $122 \pm 26^{*}$ & $1.7 \pm 0.3$ \\
TPN + peptide-B & $105 \pm 19^{*}$ & $1.4 \pm 0.2$ \\
\hline
\end{tabular}

GSH levels were higher in liver from animals infused with TPN containing peptides than in those on TPN without peptide. The two peptides had a similar effect. GSSG levels did not significantly vary between groups; means \pm SEM, $n=4-6$.

GSH, reduced form of glutathione; GSSG, disulfide form of glutathione; peptide-A, YGYTGA; peptide-B, ISELGW; TPN, total parenteral nutrition.

${ }^{*} P<0.05$.
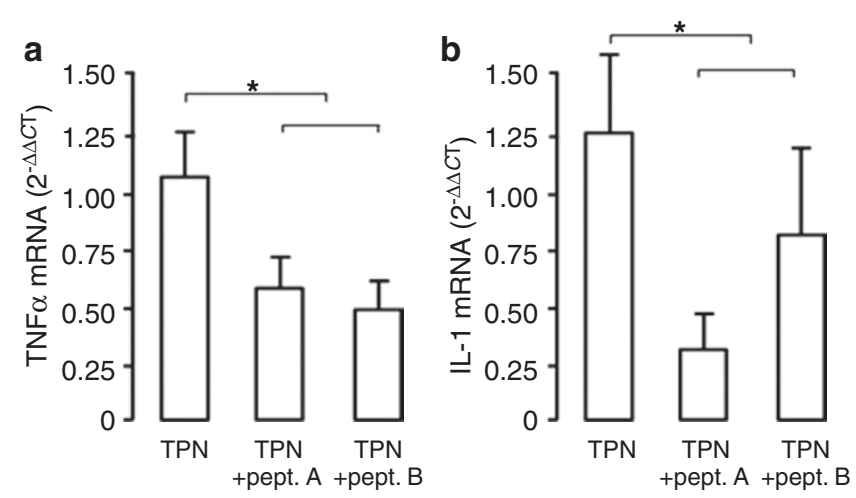

Figure 4. mRNA levels of TNFa and IL-1 in liver from animals infused with TPN with or without peptide-A or peptide-B. The mRNA levels of (a) TNFa and (b) IL-1 were lower in liver from animals infused with TPN containing peptide-A or peptide-B than in animals on TPN without peptides. The two peptides exerted similar effect; mean \pm SEM, $n=5-6$. ${ }^{*} P<0.05$. IL, interleukin; pept., peptide; pept.-A, YGYTGA; pept.-B, ISELGW; TNF, tumor necrosis factor; TPN, total parenteral nutrition.

The in vivo part of this study demonstrates that peptide-A and peptide-B have significant effects on markers of oxidative stress and on mRNA of proinflammatory cytokines. Furthermore, these effects are different from those observed in animals fed HM. The route of administration (parenteral vs. enteral), the dose, or intestinal absorption can explain the difference. For instance, the hepatic redox potentials calculated in animals infused with $\mathrm{H}_{2} \mathrm{O}_{2}$ fed with $\mathrm{AM}$ (Figure 2a), or with TPN without light protection and additional peptides (Figure 3a) were similarly oxidized. Supplementation of TPN with peptides protected this redox shift through an oxidized status whereas HM was without effect. The high GSH level in liver from the TPN + peptides groups, explaining their more reduced redox potential, suggests that peptides could favor glutathione synthesis. This provides a basis for future studies that will be important for the premature newborn population in whom the level of glutathione is low $(7,8)$ although they have a normal capacity of synthesis $(24,25)$. The fact that an early administration of amino acids in premature infants favored glutathione synthesis (24) supports the notion that the availability of amino acids may be a limiting step for this synthesis. Because both peptides contain glycine, one of the glutathione constituents, the impact of peptides on GSH levels may be derived from the hydrolysis of their amino acids. Because the maximum release of glycine from peptide is $1 \mathrm{mmol} / \mathrm{l}$ as compared with the $3 \mathrm{mmol} / \mathrm{l}$ from TPN, and because glycine is not known to be the limiting step for GSH synthesis, the probability of a greater amino acid availability explaining the higher GSH levels is not very probable. However, the hydrolysis hypothesis is nevertheless interesting. As mentioned earlier, the free radical-scavenging abilities of peptides may be related to their tyrosine or tryptophan content. The complete hydrolysis of peptides could provide $2 \mathrm{mmol} / \mathrm{l}$ tyrosine and $1 \mathrm{mmol} / \mathrm{l}$ tryptophan, which are considerably higher than the amount usually present in TPN solution: $\sim 0.04 \mathrm{mmol} / \mathrm{l}$ for tyrosine and $\sim 0.2 \mathrm{mmol} / \mathrm{l}$ for tryptophan.

On the other hand, the in vivo free radical-scavenging property of $\mathrm{HM}$ has been reproduced with peptides. Even if $\mathrm{F}_{2 \alpha}-$ isoprostane levels did not reach statistically significant difference between groups, the hepatic levels of GS-HNE were lower in animals infused with TPN containing peptides as compared with those animals receiving only TPN. Both $\mathrm{F}_{2 a}$-isoprostanes and HNE are derived from lipid peroxidation via free radical attack. In liver, HNE is detoxified during glutathionylation, in which the product, GS-HNE, is actively exported in bile (26). The fact that GS-HNE was very low $(2.4 \pm 0.2 \mathrm{pmol} / \mathrm{mg}$ protein) in liver from animals enterally nourished suggests that GS-HNE measured in animals on TPN (58.0 $\pm 9.9 \mathrm{pmol} / \mathrm{mg}$ protein $)$ could be associated with a lower bile flow, a well-known complication of TPN administration such as cholestasis. Thus, by their antioxidant properties, the tested peptides could contribute to the reduction of the incidence of cholestasis in newborns on TPN. The observation of lower mRNA levels of proinflammatory cytokines-TNF $\alpha$ and IL-1-supports the notion that these peptides exert an in vivo antioxidant property. Because the presence of these proinflammatory cytokines is cited as part of hepatic TPN-related liver diseases such as cholestasis (27), the relation between HNE and bile flow is reinforced. However, as amino acids have a main impact on the reduction of bile flow (28), HNE might have only a partial impact on cholestasis, which may be related to its inflammatory properties. Indeed, cholestasis has been shown to be associated with bacterial infection (29), a condition associated with oxidative stress (30) and generation of lipid aldehydes such as $\operatorname{HNE}(31,32)$.

The aim of this study was to test the capacity of new hexapeptides to reduce oxidative stress associated with TPN. Our results show that the hexapeptides are involved in liver antioxidant actions that are accompanied by lower levels of expression of the two cytokines. Although the beneficial effect of these peptides on hepatic cholestasis is not yet proved, this study brings hope to neonatal units where the incidence of several complications of prematurity associated with oxidative stress is high. The results also demonstrate that the enrichment of TPN solutions with these isolated peptides from HM seems more prone to improve the antioxidant defenses of the neonates than whole HM. However, before the extrapolation of these data to the clinic, further studies should delineate the optimal peptide concentrations as well as the mechanisms involved. 


\section{METHODS}

\section{Experimental Designs}

Experiment 1: to test the peptides' capacity to prevent the generation of peroxides in TPN. Peptide-A and peptide-B were identified in HM as described previously (20). The peptides (95\% purity) were synthesized by GenWay Biotech (San Diego, CA). TPN solutions were prepared with $0,10,20$, or $40 \mathrm{mmol} / \mathrm{l}$ peptide-A or peptide-B (peptides were added first) $+2.2 \%(\mathrm{w} / \mathrm{v})$ amino acids (Travasol; Baxter, Mississauga, ON, Canada) $+8.7 \%$ dextrose $+1 \%$ multivitamins (Multi-12 Pediatrics, Sandoz, Boucherville, QC, Canada) $+1.5 \%(\mathrm{v} / \mathrm{v})$ lipids (Intralipid, Fresenius Kabi, Toronto, ON, Canada). After 3-h incubation at room temperature under 66 foot-candles fluorescent light exposure, peroxide concentrations were measured.

Experiment 2: to test the effect of $H M$ vs. AM on the prevention of the induction of oxidative stress by infused peroxides. Three-d-old male Hartley guinea pigs (Charles River, St Constant, QC, Canada; body weight $=104 \pm 1 \mathrm{~g}, n=26$ ) received intravenous solutions (described in the "Intravenous protocol") via a catheter secured in the right jugular vein (21). Infusions of $200-500 \mu \mathrm{mol} / \mathrm{l}_{2} \mathrm{O}_{2}$ daily in this animal model induces hepatic lipid peroxidation as indicated by increased $\mathrm{F}_{2 a}$-isoprostane levels (21). This amount of infused peroxides was comparable to the $\sim 400 \mu \mathrm{mol} / \mathrm{l}$ peroxides (1) measured in TPN as previously reported (4) and measured in this study, of which $80 \%$ are $\mathrm{H}_{2} \mathrm{O}_{2}$ (4). At the infusion rate of $240 \mathrm{ml} / \mathrm{kg} / \mathrm{d}$, the animals received $40-120 \mu \mathrm{mol} \mathrm{H}_{2} \mathrm{O}_{2} / \mathrm{kg} / \mathrm{d}$ (21). In this study (Figure 5), $\mathrm{H}_{2} \mathrm{O}_{2}$ was administered in this range.

\section{Intravenous protocol}

1. During the first $18 \mathrm{~h}$ following catheter placement, animals received intravenous solutions containing: $1 \mathrm{U} / \mathrm{ml}$ heparin + $0.45 \%(\mathrm{w} / \mathrm{v}) \mathrm{NaCl}+8.7 \%(\mathrm{w} / \mathrm{v})$ dextrose $\pm 500 \mu \mathrm{mol} / 1 \mathrm{H}_{2} \mathrm{O}_{2}$ (infusion rate $=240 \mathrm{ml} / \mathrm{kg} / \mathrm{d}$ ). Thus, animals on $\mathrm{H}_{2} \mathrm{O}_{2}$ received $120 \mu \mathrm{mol} \mathrm{H}_{2} \mathrm{O}_{2} / \mathrm{kg} / \mathrm{d}$.

2. From day $2^{2}$ (d2) to $d 4$, during the day (6:00 AM to 6:00 PM), animals received intravenous solutions containing: $1 \mathrm{U} /$ $\mathrm{ml}$ heparin $+0.9 \% \mathrm{NaCl} \pm 755 \mu \mathrm{mol} / \mathrm{l} \mathrm{H}_{2} \mathrm{O}_{2}$ (infusion rate $=$ $150 \mathrm{ml} / \mathrm{kg} / \mathrm{d}$ ). Animals on $\mathrm{H}_{2} \mathrm{O}_{2}$ received $113 \mu \mathrm{mol} \mathrm{H}_{2} \mathrm{O}_{2} / \mathrm{kg} / \mathrm{d}$ and were fed regular chow, $\mathrm{HM}^{2}$, or AM (see the following).

3. From $\mathrm{d} 2-\mathrm{d} 4$, during the night (6:00 $\mathrm{PM}$ to $6: 00 \mathrm{AM})$, animals received intravenous solutions containing: $1 \mathrm{U} / \mathrm{ml}$ heparin + $0.45 \% \mathrm{NaCl}+5 \%$ dextrose $\pm 755 \mu \mathrm{mol} / \mathrm{l} \mathrm{H}_{2} \mathrm{O}_{2}$ (infusion rate $=$ $150 \mathrm{ml} / \mathrm{kg} / \mathrm{d}$ ). Animals on $\mathrm{H}_{2} \mathrm{O}_{2}$ received $113 \mu \mathrm{mol} \mathrm{H}_{2} \mathrm{O}_{2} / \mathrm{kg} / \mathrm{d}$.

\section{Experimental groups}

1. Group C: from $\mathrm{d} 2-\mathrm{d} 4$, animals were fed regular guinea pig chow (2041-Teklad Global High Fiber Guinea Pig Diet; Harlan-Canada, Montreal, QC, Canada) and had free access

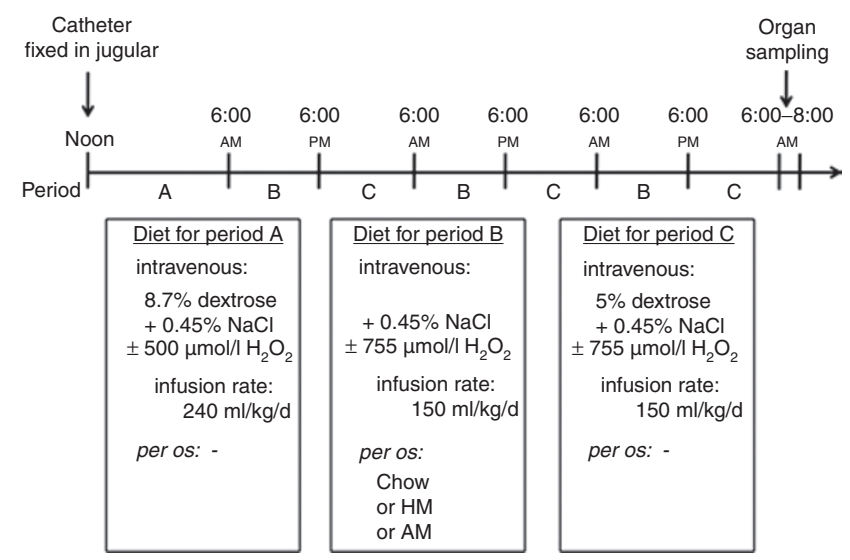

Figure 5 Experimental design for the first in vivo protocol generating data for Figure 2. AM, animals fed artificial milk; HM, animals fed human milk. to chow and water. Their intravenous solution was devoid of added $\mathrm{H}_{2} \mathrm{O}_{2}$.

2. Group $\mathrm{C}^{2}+\mathrm{H}_{2} \mathrm{O}_{2}$ : animals were fed the same diet as group $\mathrm{C}$ except that the intravenous solutions contained $\mathrm{H}_{2} \mathrm{O}_{2}$.

3. Group HM (provided from pooled human donors and lyophilized by J.K.F.): From d2-d4, every 2 h (five times a day), the mouth of the animal was filled with $1.5 \mathrm{ml}$ of reconstituted milk ( $20 \mathrm{~g}$ in $100 \mathrm{ml}$ water). Animals had free access to water. Their intravenous solution was devoid of $\mathrm{H}_{2} \mathrm{O}_{2}$.

4. Group $\mathrm{HM}+\mathrm{H}_{2} \mathrm{O}_{2}$ : animals were treated as in the $\mathrm{HM}$ group, except that their intravenous solution contained $\mathrm{H}_{2} \mathrm{O}_{2}$.

5. Group AM (prepared from Carnation Good Start; Nestle Canada, North York, ON, Canada): From d2-d4, every $2 \mathrm{~h}$ (five times a day), the mouth of the animal was filled with $1.5 \mathrm{ml}$ of AM (20 g in $100 \mathrm{ml}$ water). Animals had free access to water. Their intravenous solution was devoid of $\mathrm{H}_{2} \mathrm{O}_{2}$.

6. Group $\mathrm{AM}+\mathrm{H}_{2} \mathrm{O}_{2}$ : animals were treated as in the AM group, except that their intravenous solutions contained $\mathrm{H}_{2} \mathrm{O}_{2}$.

Experiment 3: to analyze the in vivo effect of TPN enriched with $H M$-derived specific peptides. Three-d-old guinea pig pups (body weight $99 \pm 2 \mathrm{~g}, n=17$ ) were infused with TPN solutions as previously described (21) for $4 \mathrm{~d}$ via a catheter secured in the right jugular vein. TPN was administered in a binary mode, with lipid emulsion $(1.5 \%)$ separated from other components $(1 \%$ multivitamins $+2.2 \%$ amino acid $+8.7 \%$ dextrose $\pm 1 \mathrm{mmol} / \mathrm{l}$ peptides (a concentration close to those of other amino acids in TPN)). TPN solutions were infused without light protection. The effects of peptides were compared in three groups of animals:

TPN: animals receiving TPN without addition of peptide. $\mathrm{TPN}+\mathrm{A}$ : animals receiving TPN containing $1 \mathrm{mmol} / \mathrm{l}$ peptide-A. $\mathrm{TPN}+\mathrm{B}$ : animals receiving TPN containing $1 \mathrm{mmol} / \mathrm{l}$ peptide-B.

Daily-prepared TPN solutions were infused continuously at a rate of $220 \mathrm{ml} / \mathrm{kg} / \mathrm{d}$ (animals receiving $4.8 \mathrm{~g} / \mathrm{kg} / \mathrm{d}$ of amino acids and $3.2 \mathrm{~g} /$ $\mathrm{kg} / \mathrm{d}$ of lipids).

For both in vivo protocols, after $4 \mathrm{~d}$ of treatments, the liver was collected, rinsed in $0.9 \% \mathrm{NaCl}$, rapidly minced, and aliquoted; one aliquot was immediately treated for glutathione determination and the others were stored at $-80^{\circ} \mathrm{C}$.

Guinea pigs were housed in an animal facility on a 12-h light/dark cycle at constant temperature. The study was approved by the institutional review board for the care and handling of animals (CHU SainteJustine), in accordance with guidelines of the Canadian Council of Animal Care.

\section{Methods}

GSH and GSSG were determined as previously described (1) by using the capillary electrophoresis P/ACE MDQ system (Beckman Coulter, Mississauga, Ontario, Canada). The redox potential was calculated using the Nernst equation $\left(25^{\circ} \mathrm{C}, \mathrm{pH} 7.0 ; 33\right)$.

$\mathrm{F}_{2 a}$-isoprostanes were measured (21) using a commercial enzyme immunoassay kit (Cayman Chemical, Ann Arbor, MI).

Peroxide concentrations were determined in TPN solutions by using the ferrous oxidation-xylenol orange assay as previously described (34), using $\mathrm{H}_{2} \mathrm{O}_{2}$ for the standard curve.

Hepatic levels of GS-HNE were measured by liquid chromatography electrospray ionization mass spectrometry using an Eclipse Plus C18 column coupled with an Agilent 1100 single quadrupole (Agilent, Montreal, QC, Canada). The approach used (35) is based on a differentiation of the aldehyde from the alcohol by reduction with $1 \mathrm{~mol} / \mathrm{l}$ $\mathrm{NaB}^{2} \mathrm{H}_{4}$ (Cambridge Isotope Laboratories, Andover, MA), generating stable $\left[{ }^{2} \mathrm{H}_{1}\right]$ DHN. Briefly, liver sample homogenized in buffer $(\mathrm{N}-2-$ hydroxyethylpiperazine- $\mathrm{N} 9$-2-ethanesulfonic acid: $39 \mathrm{mmol} / \mathrm{l}$, EDTA: $0.4 \mathrm{mmol} / \mathrm{l}$, butylated hydroxytoluene: $0.9 \mathrm{mmol} / \mathrm{l}, \mathrm{pH} 7.4$ ) was treated with $\mathrm{NaB}^{2} \mathrm{H}_{4}$ and spiked with the internal standard GS- $\left[{ }^{2} \mathrm{H}_{4}\right]$ DHN, made from $\left[9,9,9-{ }^{2} \mathrm{H}_{3}\right]$ trans-4-hydroxy-2-nonenal (Cayman Chemical), before proteins were precipitated by 5 -sulfosalicylic acid. GS- $\left[{ }^{2} \mathrm{H}\right] \mathrm{DHN}$ and the internal standard GS- $\left[{ }^{2} \mathrm{H}_{4}\right] \mathrm{DHN}$ were directly detected in the supernatant at $\mathrm{m} / z=467$ and 470 , respectively. 
Table 3. $5^{\prime}-3^{\prime}$ Sequences of primers used for TNFa, IL-1, and housekeeping gene $18 \mathrm{~S}$

\begin{tabular}{lll}
\hline & Primer forward & Primer reverse \\
\hline TNFa & ATCTACCTGGGAGGCGTCTT & GAGTGGCACAAGGAACTGGT \\
IL-1 & TGTGAAATGCCACCTTTTGA & GTAGCTGCCACAGCTTCTCC \\
18S & TGCATGGCCGTTCTTAGTTG & AGTTAGCATGCCAGAGTCTCGTT
\end{tabular}

The sequences were designed using Primer 3 Input software (Whitehead Institute for Biomedical Research; www.embnet.sk/cgi-bin/primer3_www.cgi).

IL, interleukin; TNF, tumor necrosis factor.

Operating parameters were a cone voltage of $60 \mathrm{~V}$, source block temperature of $350^{\circ} \mathrm{C}$, nitrogen nebulizer gas flow at $12 \mathrm{l} / \mathrm{min}$, and acquisition time between 8 and $18 \mathrm{~min}$.

Total RNA was isolated from $100 \mathrm{mg}$ of liver after homogenization in $1 \mathrm{ml}$ of Trizol (Invitrogen, Carlsbad, CA) $+200 \mu \mathrm{l}$ of chloroform and centrifuged at $31,200 \mathrm{~g}$ for $15 \mathrm{~min}$ at $4^{\circ} \mathrm{C}$. The RNA from supernatant was precipitated in $500 \mu \mathrm{l}$ isopropanol for $10 \mathrm{~min}$. After $10 \mathrm{~min}$ of centrifugation at $31,200 \mathrm{~g}$ at $4^{\circ} \mathrm{C}$, the pellet was washed in $500 \mu \mathrm{l}$ ethanol $70 \%$ and centrifuged at $31,200 \mathrm{~g}$ for $5 \mathrm{~min}$ at $4^{\circ} \mathrm{C}$. The dried pellet $\left(37^{\circ} \mathrm{C}, 1 \mathrm{~h}\right)$ was solubilized in RNase-free water. RNA concentration was determined by the ratio of absorbance read at $260 / 280 \mathrm{~nm}$. A volume of $100 \mathrm{ng}$ was reverse-transcribed by using the Quantitect Reverse transcription Kit (Qiagen, Montréal, QC, Canada). Levels of mRNA were quantified by real-time PCR using the SYBR green I labeling method. Sequences of primer sets are shown in Table 3. The amplification protocol was denaturation at $95^{\circ} \mathrm{C}$ for $5 \mathrm{~min}$ followed by 40 cycles of $95^{\circ} \mathrm{C} / 10 \mathrm{~s}, 64^{\circ} \mathrm{C} / 30 \mathrm{~s}$. mRNA levels of target genes are reported as $\Delta C_{\mathrm{T}}$ values (cycle number at which PCR target plots cross threshold, normalized to the expression levels of $18 \mathrm{~S}$ rRNA), and converted to the relative expression where $\Delta C_{\mathrm{T}}$ values of target genes are normalized to a control value, as described by Livak and Schmittgen (36).

\section{Statistical Analyses}

Data, expressed as mean \pm SEM, were compared by ANOVA after verification of the homoscedasticity by Bartlett's $\chi^{2}$-test. All comparisons were orthogonal and are described in the figures. In the first protocol (Figure 2a), the impact on redox potential of HM was compared with that of animals receiving AM. The effects of milk used as food were compared with a control group fed with regular guinea pig chow. For $\mathrm{F}_{2 \mathrm{a}}$-isoprostane determinations (Figure 2b), the comparisons were ( $\mathrm{C}$ vs. HM) vs. AM. The impacts of infusion of $\mathrm{H}_{2} \mathrm{O}_{2}$ at similar levels to those measured in TPN, according to the enteral food, were compared in a factorial ANOVA. In the second proto$\mathrm{col}$ (Figure 1), the following comparisons were made: $((40 \mathrm{mmol} / \mathrm{l}$ vs. $20 \mathrm{mmol} / \mathrm{l})$ vs. $10 \mathrm{mmol} / \mathrm{l})$ vs. $0 \mathrm{mmol} / \mathrm{l}$. In the third protocol (Figures 3 and 4), TPN containing peptide-A was compared with TPN + peptide-B, and both were compared with TPN without any peptide addition. Statistical analysis of TNFa and IL-1 mRNA levels was achieved with $\Delta C_{\mathrm{T}}$ values, and graphically represented as relative expression. The threshold of significance was assigned to $P<0.05$.

\section{STATEMENT OF FINANCIAL SUPPORT}

This work was supported by a grant from the Advanced Foods and Materials Network (Project 11F) and the Canadian Institutes for Health Research (MOP 77637).

\section{REFERENCES}

1. Chessex P, Watson C, Kaczala GW, et al. Determinants of oxidant stress in extremely low birth weight premature infants. Free Radic Biol Med 2010;49:1380-6.

2. Laborie S, Lavoie JC, Chessex P. Paradoxical role of ascorbic acid and riboflavin in solutions of total parenteral nutrition: implication in photoinduced peroxide generation. Pediatr Res 1998;43:601-6.

3. Lavoie JC, Bélanger S, Spalinger M, Chessex P. Admixture of a multivitamin preparation to parenteral nutrition: the major contributor to in vitro generation of peroxides. Pediatrics 1997;99:E6.
4. Pitkänen OM. Peroxidation of lipid emulsions: a hazard for the premature infant receiving parenteral nutrition? Free Radic Biol Med 1992;13:239-45.

5. Pitkänen $\mathrm{O}$, Hallman $\mathrm{M}$, Andersson S. Generation of free radicals in lipid emulsion used in parenteral nutrition. Pediatr Res 1991;29:56-9.

6. Srivastava SK, Singhal SS, Awasthi S, Pikula S, Ansari NH, Awasthi YC. A glutathione S-transferases isozyme (bGST 5.8) involved in the metabolism of 4-hydroxy-2-trans-nonenal is localized in bovine lens epithelium. Exp Eye Res 1996;63:329-37.

7. Thibeault DW. The precarious antioxidant defenses of the preterm infant. Am J Perinatol 2000;17:167-81.

8. Lavoie JC, Chessex P. Gender and maturation affect glutathione status in human neonatal tissues. Free Radic Biol Med 1997;23:648-57.

9. Lee JW, Davis JM. Future applications of antioxidants in premature infants. Curr Opin Pediatr 2011;23:161-6.

10. Saugstad OD. Oxygen and oxidative stress in bronchopulmonary dysplasia. J Perinat Med 2010;38:571-7.

11. Weinberger B, Watorek K, Strauss R, Witz G, Hiatt M, Hegyi T. Association of lipid peroxidation with hepatocellular injury in preterm infants. Crit Care 2002;6:521-5.

12. Uchida K, Szweda LI, Chae HZ, Stadtman ER. Immunochemical detection of 4-hydroxynonenal protein adducts in oxidized hepatocytes. Proc Natl Acad Sci USA 1993;90:8742-6.

13. Guichardant M, Taibi-Tronche P, Fay LB, Lagarde M. Covalent modifications of aminophospholipids by 4-hydroxynonenal. Free Radic Biol Med 1998;25:1049-56.

14. Kowalczyk P, Ciesla JM, Komisarski M, Kusmierek JT, Tudek B. Longchain adducts of trans-4-hydroxy-2-nonenal to DNA bases cause recombination, base substitutions and frameshift mutations in M13 phage. Mutat Res 2004;550:33-48.

15. Liu W, Kato M, Akhand AA, et al. 4-hydroxynonenal induces a cellular redox status-related activation of the caspase cascade for apoptotic cell death. J Cell Sci 2000;113 (Pt 4):635-41.

16. Ruef J, Moser M, Bode C, Kübler W, Runge MS. 4-hydroxynonenal induces apoptosis, NF-kB-activation and formation of 8-isoprostane in vascular smooth muscle cells. Basic Res Cardiol 2001;96:143-50.

17. Ledo A, Arduini A, Asensi MA, et al. Human milk enhances antioxidant defenses against hydroxyl radical aggression in preterm infants. Am J Clin Nutr 2009;89:210-5.

18. Friel JK, Martin SM, Langdon M, Herzberg GR, Buettner GR. Milk from mothers of both premature and full-term infants provides better antioxidant protection than does infant formula. Pediatr Res 2002;51:612-8.

19. Shoji H, Oguchi S, Shimizu T, Yamashiro Y. Effect of human breast milk on urinary 8-hydroxy-2'-deoxyguanosine excretion in infants. Pediatr Res 2003;53:850-2.

20. Tsopmo A, Romanowski A, Banda L, Lavoie J, Jenssen H, Friel J. Novel anti-oxidative peptides from enzymatic digestion of human milk. Food Chem 2011;126:1138-43.

21. Chessex P, Lavoie JC, Rouleau T, et al. Photooxidation of parenteral multivitamins induces hepatic steatosis in a neonatal guinea pig model of intravenous nutrition. Pediatr Res 2002;52:958-63.

22. Davies MJ, Fu S, Wang H, Dean RT. Stable markers of oxidant damage to proteins and their application in the study of human disease. Free Radic Biol Med 1999;27:1151-63.

23. Tsopmo A, Diehl-Jones BW, Aluko RE, Kitts DD, Elisia I, Friel JK. Tryptophan released from mother's milk has antioxidant properties. Pediatr Res 2009;66:614-8.

24. Te Braake FW, Schierbeek H, de Groof K, et al. Glutathione synthesis rates after amino acid administration directly after birth in preterm infants. Am J Clin Nutr 2008;88:333-9.

25. Lavoie JC, Chessex P. Development of glutathione synthesis and $\gamma$-glutamyltranspeptidase activities in tissues from newborn infants. Free Radic Biol Med 1998;24:994-1001.

26. Pedersen WA, Cashman NR, Mattson MP. The lipid peroxidation product 4-hydroxynonenal impairs glutamate and glucose transport and choline acetyltransferase activity in NSC-19 motor neuron cells. Exp Neurol 1999;155:1-10. 
27. Donner MG, Schumacher S, Warskulat U, Heinemann J, Häussinger D. Obstructive cholestasis induces TNF- $\alpha$ - and IL-1-mediated periportal downregulation of Bsep and zonal regulation of Ntcp, Oatpla4, and Oatp1b2. Am J Physiol Gastrointest Liver Physiol 2007;293:G1134-46.

28. Lavoie JC, Chessex P, Gauthier C, et al. Reduced bile flow associated with parenteral nutrition is independent of oxidant load and parenteral multivitamins. J Pediatr Gastroenterol Nutr 2005;41:108-14.

29. Wolf A, Pohlandt F. Bacterial infection: the main cause of acute cholestasis in newborn infants receiving short-term parenteral nutrition. J Pediatr Gastroenterol Nutr 1989;8:297-303.

30. Sebai H, Sani M, Yacoubi MT, Aouani E, Ghanem-Boughanmi N, Ben-Attia M. Resveratrol, a red wine polyphenol, attenuates lipopolysaccharide-induced oxidative stress in rat liver. Ecotoxicol Environ Saf 2010;73:1078-83.

31. Sebai H, Sani M, Aouani E, Ghanem-Boughanmi N. Cardioprotective effect of resveratrol on lipopolysaccharide-induced oxidative stress in rat. Drug Chem Toxicol 2011;34:146-50.
32. Fagundes DS, Gonzalo S, Arruebo MP, Plaza MA, Murillo MD. Melatonin and Trolox ameliorate duodenal LPS-induced disturbances and oxidative stress. Dig Liver Dis 2010;42:40-4.

33. Schafer FQ, Buettner GR. Redox environment of the cell as viewed through the redox state of the glutathione disulfide/glutathione couple. Free Radic Biol Med 2001;30:1191-212.

34. Lavoie JC, Laborie S, Rouleau T, Spalinger M, Chessex P. Peroxide-like oxidant response in lungs of newborn guinea pigs following the parenteral infusion of a multivitamin preparation. Biochem Pharmacol 2000;60:1297-303.

35. Véronneau $M$, Comte $B$, Des Rosiers C. Quantitative gas chromatographic-mass spectrometric assay of 4-hydroxynonenal bound to thiol proteins in ischemic/reperfused rat hearts. Free Radic Biol Med 2002;33:1380-8.

36. Livak KJ, Schmittgen TD. Analysis of relative gene expression data using real-time quantitative PCR and the 2(-Delta Delta C(T)) method. Methods 2001;25:402-8. 